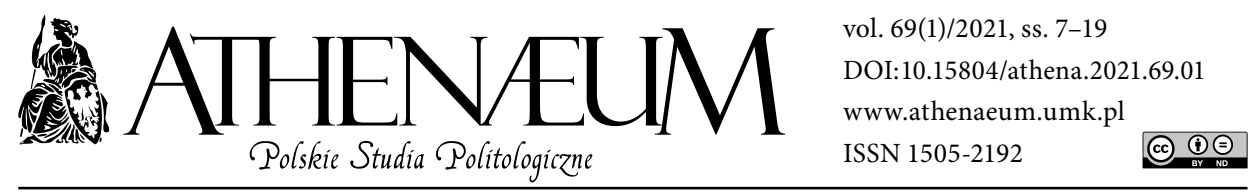

\title{
REWOLUCJA JAKO NARZĘDZIE EMANCYPACJI W MYŚLI SPOŁECZNO-POLITYCZNEJ SLAVOJA ŽIŽKA
}

\author{
REVOLUTION AS A TOOL FOR EMANCIPATION IN SLAVOJ \\ ŽIŽEK'S SOCIAL AND POLITICAL THOUGHT
}

\author{
Sławomir Drelich* ${ }^{*}$
}

\begin{abstract}
ABSTRAKT
W artykule podjęty został temat relacji między rewolucją a postulatem emancypacji w myśli społeczno-politycznej Slavoja Žižka. Autor wskazuje, że w tekstach myśliciela rewolucja jest jedynym skutecznym narzędziem prawdziwej emancypacji klas społecznych wykluczonych. Artykuł jest efektem analizy treści zawartych w najważniejszych tekstach Žižka, w których poruszana jest tematyka rewolucji. Autor stosuje podejście interpretatywne i metodę hermeneutyczno-fenomenologiczną. Analiza dokonana została w trzech etapach. W etapie pierwszym autor wskazuje, że rewolucja jest u Žižka kwintesencją krytyki obowiązującego w społeczeństwie porządku symbolicznego. W drugim etapie autor dowodzi, że rewolucja jest formą radykalnego działania politycznego, które przynosi prawdziwą zmianę porządku. W trzecim etapie rewolucja zostaje ukazana jako wybuch oddolnej wolności i demokracji mas społecznych.
\end{abstract}

Słowa kluczowe: rewolucja; emancypacja; Slavoj Žižek; wykluczeni; porządek symboliczny
The article discusses the relation between revolution and emancipation postulates in Slavoj Žižek's social and political thought. In his texts, the author points out that the revolution is the only tool for the real emancipation of the excluded classes. The article is the result of the content analysis of few of the most important Žižek's texts on revolution. The author uses an interpretative approach as well as hermeneutic and phenomenological methods. The analysis was made in three stages. In the first stage, the author points out that the revolution in Žižek's thought is the quintessence of criticism of the symbolic order of the society. In the second stage, the author proves that revolution is a form of a radical political action that brings about a real change of order. In the third stage, the revolution is presented as an outbreak of freedom and democracy.

Keywords: revolution; emancipation; Slavoj Žižek; excluded class; symbolic order

* Uniwersytet Mikołaja Kopernika w Toruniu, Wydział Nauk o Polityce i Bezpieczeństwie. 


\section{IDEA REWOLUCJI W MYŚLI SPOŁECZNO-POLITYCZNEJ ŽIŽKA - WPROWADZENIE}

Slavoj Žižek w Przekleństwie wyobraźni wspomina ideologiczne rozczarowanie, jakie rzekomo wstrząsnęło Leninem, kiedy w 1914 r. „zobaczył codzienną gazetę niemieckiej socjaldemokracji, ogłaszającą na pierwszej stronie, że socjaldemokratyczni deputowani głosowali za kredytami wojennymi" (Žižek, 2001, s. 67). Lenin - jak wskazuje Žižek - początkowo był przekonany, że to policja niemiecka ów artykuł sfabrykowała. Gdy relacja okazała się prawdą, ocenił ją jako zdradę podstawowych wartości radykalnej lewicy. Przekonywał, że partie socjaldemokratyczne zwyczajnie „dały upust szowinizmowi” (Žižek, 2018, s. 279). Zachowanie niemieckich socjaldemokratów skłoniło Lenina do postawienia na nowo pytań o radykalny projekt przebudowy społeczeństwa - pytań, które stawia w swoich tekstach również Žižek. Dyskusja wokół kontrowersyjnych propozycji ideologicznych i teoretycznych słoweńskiego filozofa, w szczególności wokół tych, które wywiązały się po opublikowaniu przez niego Rewolucji u bram (Žižek, 2007), rozgorzała zarówno w międzynarodowej, jak i polskiej debacie akademickiej. Książka ta - zdaniem części badaczy - wywołała „być może najbardziej burzliwą w III RP (...) debatę wokół książki filozoficznej” (Wójcik, 2016, s. 19) - tym bardziej więc warto sięgnąć do pewnych propozycji w niej zawartych i poszerzyć je o refleksje podejmowane przez Žižka w innych publikacjach.

Głównym problemem badawczym podjętym w tekście są formy relacji między koncepcją rewolucji a postulatem emancypacji. Pytanie badawcze, na które będziemy usiłowali odpowiedzieć, brzmi: Jaki jest związek między rewolucją a postulatami emancypacyjnymi na gruncie myśli społeczno-politycznej Žižka? Udzielenie odpowiedzi na to pytanie przeprowadzone zostanie w trzech krokach: (1) ukazanie, iż sformułowana przez Žižka koncepcja rewolucji rodzi się z głębokiej krytyki porządku symbolicznego, w którym krytykujące go grupy społeczne funkcjonują; (2) przedstawienie rewolucji jako radykalnej formy działania politycznego, która jako jedyna pozwala na implementację projektu gruntownej przebudowy ładu społecznego; (3) ujęcie rewolucji jako efektu eksplozji wolności niezadowolonych mas społecznych i kwintesencji żywiołowej demokracji bezpośredniej.

Niniejszy tekst jest efektem jakościowej analizy treści zawartych w rozproszonych tekstach Žižka, w których pojawiają się wątki związane z rewolucją. Dobór poddanych badaniu materiałów miał charakter celowy. Tekst ma charakter monograficzny, natomiast oparto go na podejściu interpretatywnym - celem 
bowiem ma być uchwycenie punktu widzenia zaproponowanego przez Žižka. Przyjęto metodę hermeneutyczno-fenomenologiczną, pozwalającą na krytyczne i pogłębione odczytanie idei słoweńskiego filozofa. Choć myśl społeczno-polityczna Žižka często jest przedmiotem analiz badaczy zajmujących się myślą polityczną oraz filozofią polityki, to jednak większość prowadzonych badań dotyczy historiozoficznych, marksistowskich i psychoanalitycznych wątków jego koncepcji (Burzyk, 2013; Dybel, 2014; Finlay, 2006; McMillan, 2012; Miklitsch, 1998; Vighi, 2010; Wójcik, 2014). Z kolei badania obejmujące jego koncepcję rewolucji ograniczają się głównie do rozważań poświęconych sensu stricto wydarzeniom rewolucji bolszewickiej (Bjerre, Laustsen, 2010; Breckman, 2016; Khader, Rothenberg, 2013; Sigurdson, 2012). Niniejszy tekst jest zatem również próbą ukazania myśli Žižka w kontekście teorii rewolucji.

\section{KROK 1: REWOLUCJA JAKO KRYTYKA PORZĄDKU SYMBOLICZNEGO}

Žižek proponuje wyjście poza klasyczną i instytucjonalną interpretację rewolucji. Zgadza się, że rewolucja stanowi zawsze mechanizm zmiany instytucji władzy; zgadza się również, że istotną rolę w tym wydarzeniu ogrywają elity polityczne oraz partie (Mazur, 2017, s. 16). Uważa jednak, że to przeobrażenie instytucjonalno-ustrojowe jest jedynie efektem głębszej zmiany, którą rewolucja powoduje: zmiany porządku symbolicznego, czyli - mówiąc językiem psychoanalizy Jacquesa Lacana - „wielkiego Innego”. Choć porządek symboliczny - jak wskazują współcześni lacaniści - może być postrzegany zarówno jako ów wielki Inny, jak też jako zbiór kategorii języka (Jameson, 2010, s. 268), to jednak u Žižka trudno oba te poziomy rozróżnić. Wielki Inny czy też porządek symboliczny to „niepisana konstytucja społeczeństwa” (Žižek, 2008a, s. 21), „mechanizm porządkujący chaos" (Žižek, 2018, s. 62), czyli struktura znaczeń, które pozwalają jednostce postrzegać i rozumieć otaczający świat. Jak wskazuje autor Rewolucji u bram, ,porządek symboliczny nie jest rodzajem duchowej substancji istniejącej niezależnie od jednostek, ale czymś podtrzymywanym przez ich nieustanną aktywność" (Žižek, 2008a, s. 24). Rewolucja stanowi radykalne odwrócenie porządku symbolicznego - obalenie dotychczasowego ładu symbolicznego dokonuje się zaś poprzez radykalne działanie, radykalny czyn, który stanowi odwrócenie bierności. Jak się zatem okazuje, „robienie niczego nie jest czymś pustym, ale od razu ma swoje znaczenie - oznacza zgodę na istniejące stosunki 
panowania" (Žižek, 2007, s. 367). Radykalna niezgoda musi więc przejawiać się w rewolucji. Nie należy zatem bać się stwierdzenia, że rewolucja jest „formą ekstremizmu”. W efekcie działania rewolucyjnego „zmienia się sama miara ustalająca, co jest skrajne. (...) Zmienia się całość, zmienia się sama miara ekstremów" (Žižek, 2014b, s. 17). Nowy porządek symboliczny redefiniuje to, co dotychczas postrzegano jako skrajne.

Žižek przyjmuje perspektywę marksistowską, jednak nawet ją wyostrza. Wskazuje, że wszelka rewolucja odbywa się tam, gdzie „antagonizmy rozwoju kapitalistycznego są najpoważniejsze, nawet jeśli jest on mniej rozwinięty" (Žižek, 2008b, s. 178), jak to było chociażby w Rosji w 1917 r. Walka klas jest dla Žižka formą interpretacyjną, której kulminacją jest rewolucja, a punktem wyjścia - przeświadczenie każdej z zantagonizowanych klas, iż to ona stanowi społeczeństwo sensu stricto, drugą degradując do rangi „nie-społeczeństwa”. Walka klas stanowi zasadę walki emancypacyjnej (Flisfeder, 2008, s. 5-6), czyli sposób „nadania” właściwej roli społeczeństwu sensu stricto, a zlikwidowania tego, co określa się mianem „nie-społeczeństwa”. Paradoksalnie okazuje się, że „jedyny dobry bliźni to martwy bliźni”, natomiast śmierć tego „bliźniego” jako jedyna „niweluje wszelkie różnice” (Žižek, 2007, s. 402-409). Žižek zgadza się z Ernesto Laclauem, iż atak na wroga jest warunkiem wstępnym każdej zbiorowej tożsamości (Laclau, 2006, s. 648), tym samym rewolucja pozwala na ukonstytuowanie się nowemu społeczeństwu. Laclau i Chantal Mouffe twierdzą wręcz, że „społeczeństwo nie istnieje” czy też że „społeczeństwo nie jest pozytywnym polem” (Žižek, 2007, s. 340). Antagonizmy powodują konflikty, uniemożliwiając klasom społecznym materializację własnej tożsamości, bo „o ile istnieje antagonizm, nie mogę [ja jako członek określonej klasy - przyp. S.D.] być sam dla siebie pełnią obecności” (Laclau, Mouffe, 2007, s. 135). Žižek jest przekonany, że „zaostrzenie walki klasowej” będzie konieczne jako „dźwignia wzmacniająca antagonizmy, by możliwy był rewolucyjny wybuch" (Žižek, 2008b, s. 318). Rewolucja dokonuje się poprzez pogłębienie antagonizmów, których kulminacją ma być eksplozja emancypacyjna klasy podporządkowanej: wykluczonych i pokrzywdzonych.

Žižek - powołując się na Hegla - stwierdza, że w sprzyjających okolicznościach najbardziej pokrzywdzone i wykluczone warstwy społeczeństwa zbuntują się i zorganizują rewolucję (Burman, 2018, s. 193). Rewolta najsłabszych obnaży bezsilność władzy (Žižek, 2020, s. 134), która ulegnie zaskoczeniu mobilizacją tych, którzy dotychczas stanowili „nie-społeczeństwo”. Autor Rewolucji u bram przywołuje przykład Lenina, który od swoich współpracowników domagał się pełnego zaangażowania w mobilizację klasy robotniczej, zdając sobie sprawę, 
że organizacja zrzeszająca uświadomiony proletariat będzie potrafiła „obudzić Rosję i obalić carat” (Žižek, 2017, s. LXIV). Choć kategoria „proletariatu” zdaje się współcześnie anachroniczna, to jednak Žižek wskazuje, że w kontekście każdej rewolucji - tak byłej, jak też przyszłej - zasadnym jest mówić o ludziach, którzy znajdują się w „położeniu proletariackim” (Žižek, 2014b, s. 72) lub osobach o „statusie proletariusza” (Žižek, 2014a, s. 33). To oni stanowią „nie-społeczeństwo” ludzi o statusie paradoksalnym: koniecznych dla przetrwania klasy panującej, jednak wykluczonych z podmiotowego uczestnictwa w społeczeństwie (Flisfeder, 2008, s. 3). Tak rozumianym proletariuszom Žižek nadaje status Agambenowskiego homo sacera (Žižek, 2016, s. 246). Homo sacer to człowiek wykluczony i pozbawiony praw, osoba, która zostaje „umieszczana poza ludzką jurysdykcją, czemu nie towarzyszy przejście w zasięg jurysdykcji boskiej" (Agamben, 2008, s. 114). Człowieka takiego można zabić, jednak nie można go złożyć w ofierze, a zatem „dopuszczalność zabójstwa implikowała to, że zadany mu gwałt nie stanowił świętokradztwa" (Agamben, 2008, s. 114). Homo sacer nie ma nic do stracenia, skoro jego życie okazuje się bez wartości, jego „podstawowym prawem jest prawo do opowiedzenia o własnym doświadczeniu bólu i poniżenia" (Žižek, 2007, s. 325). Rewolucja stanowić może jedyną skuteczną drogę do emancypacji, czyli prawdziwego wyzwolenia uciemiężonych. Dla Žižka Antygona jest wzorcem rewolucjonisty jako „przednowoczesna emancypantka-heroina” (Žižek, 2016, s. 245) - Antygona, która podważa panujący porządek symboliczny, stając po stronie tego, co zmarginalizowane.

\section{KROK 2: REWOLUCJA JAKO WIZJA PRAWDZIWEGO RADYKALIZMU}

Antygona jest dla Žižka - podobnie zresztą jak Lenin - symbolem prawdziwego radykalizmu. Zajmuje ona „stanowisko bezgranicznego uporu, który burzy "piękny porządek « miasta" (Žižek, 2016, s. 244). Ponownie stanowisko autora Rewolucji u bram zdaje się odpowiadać koncepcji polityczności Laclaua i Mouffe'a, w której antagonizm uczyniono formułą niemalże immanentną. Prawdziwa polityka - polityka radykalna - domaga się dokonania odważnego wyboru między alternatywami nieprzystawalnymi, gdyż przyjęcie opcji pośredniej nie jest możliwe (Przyłęcki, 2013, s. 19; Laclau, 1990, s. 35). Žižek ubolewa, że w liberalno-demokratycznych ramach brak dziś prawdziwego radykalizmu, nawet wśród środowisk, które roszczą sobie pretensje do nazywania się mianem lewicy. 
Drwi z „pseudoradykalnych lewaków z uniwersytetów”, z których „ogromna większość (...) po cichu liczy na długotrwałą stabilność amerykańskiego modelu kapitalizmu" (Žižek, 2007, ss. 314-315) i utrzymanie aktualnego porządku symbolicznego, którego są beneficjentami. Žižek ubolewa, że w demoliberalnym świecie "tolerowane są te zwyczaje Innego, które nie czynią nikomu krzywdy” (Žižek, 2007, s. 319), a w konsekwencji nie prowadzą do realnej przebudowy systemu. Akceptowalne są wyłącznie takie działania, które odpowiadają logice panującego porządku i zapewniają jego przetrwanie, choćby w warstwie retorycznej objawiały się krytycyzmem. Słoweński filozof pochwala odwagę bolszewików z 1917 r., którzy - mówiąc słowami Johna Reeda, amerykańskiego dziennikarza komunistycznego - „skończyli ze wszystkimi fałszywymi kompromisami” (Reed, 1956, s. 6). Jedynie rewolucja postrzegana jako radykalna przebudowa porządku społecznego daje szansę na emancypację - wszelkie próby korekty panującego systemu de facto prowadzą do utrzymania stosunków opartych na wykluczeniu i panowaniu.

Rewolucja jest sprzeciwem wobec obowiązującej powszechnie w demokracji „doksie kompromisu” (Žižek, 2007, s. 327), a przecież za bojownikami emancypacji stoi słuszne żądanie wyzwolenia, które nie powinno podlegać żadnym uzgodnieniom. W Przekleństwie fantazji Žižek przedstawia rewolucje jako „wydarzenia uniwersalnej Prawdy”, proletariat zaś jawi się jako zbiorowy „bojownik o uniwersalną Prawdę”. Chodzi mu oczywiście - jak już wskazywano - nie o proletariat sensu stricto, ale raczej o „podmiot proletariacki”, którym może być każda grupa społeczna wykluczona czy też o nadanym piętnie homo sacera. „Podmiot proletariacki” godzi się „przyjąć określoną postawę subiektywną” (Žižek, 2001, s. 100), czyli dokonać kolejnego etapu walki klasowej, której finalizacją będzie rewolucja. Ludzie znajdujący się w położeniu proletariackim dokonują swoistego aktu zdrady względem ładu społeczno-politycznego i porządku symbolicznego, jednakże ów „akt zdrady jest najwyższym aktem miłości” (Žižek, 2016, s. 239). Miłość skierowana jest ku wszystkim zmarginalizowanym, ale również ku marzeniu o lepszej przyszłości. Droga do lepszej przyszłości prowadzi jednak przez wszelkie ekscesy gwałtownej przebudowy: terror, mordy czy też iście barbarzyńskie zniszczenie. Jeśli sukces emancypacyjny ma stać się faktem, wówczas nie da się uniknąć ekstremizmu rewolty, bo nie da się zrobić „rewolucji bez rewolucji” (Žižek, 2007, ss. 511-512). Rewolucyjny terror nie oznacza jednak ślepych aktów przemocy - tutaj Žižek odróżnia „prawdziwie” rewolucyjny terror czasów leninowskich od praktyk stalinizmu - ale dokonuje się on poprzez „autentyczne akty wyzwolenia (Žižek, 2007, s. 515), które odbywają się otwarcie 
i jawnie, stanowiąc jednocześnie węgielny kamień nowego porządku. Konieczność rewolucyjnego zniszczenia tłumaczy Žižek odniesieniami do Freudowskiej psychoanalizy, a w szczególności do rozważań dotyczących popędu śmierci (tanatosa), destrukcyjnego i niszczycielskiego, stanowiącego bodziec do wielkich czynów oraz realizacji imponujących wyzwań (Žižek, 2016, s. 240; Freud, 1994, s. 102; Kaczmarek, 2015, s. 42). Co ważne, Freudowski tanatos - swoista „próba negacji”, która „jest w stanie rozsadzić każdy społeczno-kulturowy porządek” (Dybel, 1996, s. 217) - jest również siłą kierującą jednostkami wyczulonymi na ludzką krzywdę i tęskniącymi za ziszczeniem się idei sprawiedliwości społecznej (Dybel, 1996, ss. 96-97; John, Pervin, 2011, s. 89).

Rewolucja jako czyn prawdziwie radykalny ma za zadanie przede wszystkim - tutaj Žižek powołuje się na Theodora Adorna - „zakwestionować wytyczne panującej ideologii” (Žižek, 2007, s. 310), nie wiedząc jednocześnie, co będzie dalej i czy wydarzenia rewolucyjne w istocie przyniosą spełnienie się marzeń o emancypacji. Rewolucjonista wykazać się musi postawą egzystencjalną typową dla prawdziwie wierzącego (Boucher, 2020, s. 253), który nie kwestionuje kierunku swojego działania i postawionego sobie celu. Nie może on czekać na uzyskanie przez rewolucjonistów powszechnej społecznej legitymizacji - taki „strach przed otchłanią" nie jest niczym innym, jak próbą oparcia radykalizmu rewolucji na wielkim Innym, a przecież eidos rewolucji jest właśnie zerwaniem z tym wielkim Innym (Žižek, 2011, s. 33). Ze względu na swój radykalizm rewolucja jest sprzeczna $z$ logiką działania sił politycznych w liberalnej demokracji, w której co do zasady „zmieniamy coś ciągle, aby ogólnie rzecz biorąc, wszystko pozostało bez zmian!” (Žižek, 2007, s. 311). Reprodukcja porządku symbolicznego dokonuje się poprzez różnorodne formy symulacji sprzeciwu wobec panującego porządku. Žižek wskazuje, że przecież „możemy cieszyć się kawą bez kofeiny, piwem bez alkoholu, seksem bez bezpośredniego kontaktu fizycznego (...); możemy nawet otrzymać etnicznego Innego, pozbawionego substancji swojej Inności” (Žižek, 2007, s. 319). Nadal pozostajemy jednak $\mathrm{w}$ ramach obowiązującego systemu, w najmniejszym stopniu nie podważając jego fundamentów. Radykalizm rewolucjonistów polega na tym, że „najpierw stary porządek zostaje zanegowany w ramach swojej ideologiczno-politycznej formy; następnie zanegowana zostaje sama ta forma” (Žižek, 2007, s. 30) - prawdziwy radykalizm domaga się zerwania $z$ demokratyczną iluzją (Žižek, 2008c, s. LXXX). Prawdziwa emancypacja dokona się zatem nie poprzez legalne i demokratyczne przejęcie władzy przez konkurencyjne względem tradycyjnych siły polityczne, ale poprzez samo podważenie fundamentów systemu. 


\section{KROK 3: REWOLUCJA JAKO ODDOLNA EKSPLOZJA WOLNOŚCI}

Žižek prezentuje szereg obrazów, które pozwalają rewolucję ujmować jako siłę umożliwiającą emancypację. Perspektywa społeczna, jaką proponuje, pozwala postrzegać rewolucyjne działania jako „eksplozję wolności we wzniosłym entuzjazmie”, „magiczny moment powszechnej solidarności” czy też jako „ciężką pracę społecznej rekonstrukcji” (Žižek, 2007, s. 39). Także Orlando Figes rewolucję ukazuje jako swoistą erupcję wulkanu, która wciąga głównych swych aktorów (Hobsbawm, 1996, s. 3). Wolność zdaje się cechować rewolucjonistów, którzy nie oglądają się za siebie, porzucają świat symboliczny, w którym wyrośli, i zdecydowanie domagają się wyzwolenia. Dla Žižka to właśnie Lenin symbolizuje „nieodpartą wolność zawieszenia istniejących (post)ideologicznych współrzędnych, ogłupiającego Denkverbot (zakazu myślenia), w którym żyjemy" (Žižek, 2007, s. 47). Prawdziwa wolność okazuje się zatem odwagą kwestionowania porządku społeczno-politycznego. Nie można więc wolności interpretować w duchu liberalno-demokratycznym i naiwnie postrzegać ją jako „błogi, neutralny stan harmonii i równowagi”. Prawdziwa wolność równowagę zakłóca, a jako radykalny gest odrzucenia, staje się podstawą na nowo zdefiniowanej przez rewolucjonistów różnicy, wytyczenia linii oddzielającej porządek stary, przeznaczony do zniszczenia, od porządku nowego (Žižek, 2008c, s. XLVII). Žižkowski rewolucyjny woluntaryzm ignoruje prawo i tradycję, bezlitośnie pozbywa się „wrogów ludu” przy pomocy narzędzi terroru, narzuca „egalitarną sprawiedliwość" (Žižek, 2008b, s. 157). Jest to raczej gwałtowny akt, który zamiast zapewniać pokojowe współistnienie - wszelką równowagę burzy (Žižek, 2006, s. 55). Redefinicja wolności zdaje się być również formą ustanowienia nowego, rewolucyjnego porządku symbolicznego.

Eksplozja rewolucyjnej wolności jest dla Žižka ucieleśnieniem rzeczywistej demokracji. Już w wydarzeniach rewolucji bolszewickiej dostrzegał „niewiarygodną eksplozję demokracji oddolnej, lokalnych komitetów powstających w więksszych miastach całej Rosji” (Žižek, 2007, s. 38). Każda rewolucja jest kulminacją wcześniejszych emancypacyjnych buntów, których organizatorom nie udało się przezwyciężyć. Można przyjąć, że rewolucja zwieńczona sukcesem realizuje potencjał nieudanych prób rewolucyjnych (Žižek, 1992, s. 80). Wspomniany wcześniej Figes, jak również Eric Hobsbawm, sprzeciwiają się używaniu terminu „pucz” na określenie rosyjskich wydarzeń rewolucyjnych 1917 r., a widzą w nich - podobnie jak Žižek - „rewolucję mas” (Hobsbawm, 1996, s. 4). Tym bardziej nie dziwi przeświadczenie Reeda, jakoby sama instytucja rad robotni- 
czych i żołnierskich była wspaniałym dowodem organizacyjnego geniuszu mas rosyjskich (Reed, 1956, s. 5). Według Hobsbawma Rosja po obaleniu caratu stała się de facto anarchią, w której rządy sprawowała volya (wola), nie uznająca żadnej władzy (Hobsbawm, 1996, s. 4). Warunkiem takiej rewolucyjnej spontanicznej demokracji była „świadomość klasowa” rewolucjonistów. Ta jednakże nie rodzi się - tutaj Žižek zgadza się z Leninem - spontanicznie, ale kształtowana jest żmudną pracą intelektualistów i liderów partyjno-związkowych (Žižek, 2017, s. LXIII; Žižek, 2007, s. 354). Tylko odpowiednio ukształtowana świadomość klasowa pozwala na doprowadzenie wydarzeń rewolucyjnych do końca. Autor Rewolucji u bram jest przeświadczony, że ten czynnik - niekoniecznie zaś osiągnięcie określonego stopnia rozwoju gospodarczego - doprowadził do tego, że po rewolucji lutowej Rosja była „najbardziej demokratycznym krajem w całej Europie, $\mathrm{z}$ bezprecedensowym poziomem masowej mobilizacji, wolnością zrzeszania się i wolnością prasy" (Žižek, 2007, s. 38-39). Te prawdziwie demokratyczne warunki umożliwiły dopiero rewolucję, nie był to bowiem cel sam w sobie zrewoltowanych mas.

Także Hobsbawm wskazuje, że to raczej doświadczenie równości społecznej, jakiej rosyjskie masy doznały w 1917 r., stało się iskrą październikowej rewolucji. Tym samym porewolucyjny terror komunistyczny miał swoje ludowe podstawy, dlatego nie należy go traktować jedynie jako narzędzia represji komunistycznych władców (Hobsbawm, 1996, 4-5). Choć więc w trakcie rewolucji „przemoc wyślizguje (...) się w stronę szaleństwa" (Žižek, 2016, s. 242), to jednak tylko w ten sposób rewolucje - mówiąc słowami Marksa - mogą stać się „lokomotywami historii”. Dopiero ci, którzy historię piszą post factum, będą w stanie odróżnić „fałszywe wybuchy przemocy” od „cudu prawdziwego rewolucyjnego przełomu” (Žižek, 2007, s. 507). Rewolucjoniści nigdy nie wiedzą, jaki będzie porewolucyjny „nowy człowiek”, a rewolucja nigdy nie jest legitymizacją jakiejś konkretnej całościowej koncepcji społecznej, politycznej czy ustrojowej. Emancypacyjny cel nie zakłada konkretnej formy polityczno-prawnego porządku. Legitymizacja rewolucji ma charakter negatywny, stanowi materializację woli zerwania z przeszłością (Žižek, 2008c, s. LXXV). Komunizm, który był dla bolszewików hasłem na określenie „nowego porządku”, nie może być - zdaniem Žižka - utożsamiany z formą ustroju politycznego. Przekonuje, że „komunizm to nie nazwa rozwiązania, lecz problemu: problemu wspólności we wszystkich wymiarach” (Žižek, 2014b, s. 32). Tym samym postulat komunizmu może być zawsze aktualny, choć uzyskiwać może odmienne społeczno-polityczne, gospodarcze i prawno-ustrojowe materializacje. Analogicznie „dyktatura proletariatu” nie odnosi się do reżimu czy 
systemu politycznego, ale raczej do ogólnej logiki porządku symbolicznego, który opiera się na interesach wyemancypowanych grup proletariatu (Žižek, 2008b, s. 368). Nie ma powodu, aby unikać kategorii „interesu” - emancypacja dotyczy bowiem zawsze tych, którzy aktualnie znajdują się w położeniu proletariackim i to ich interesy realizowane są $\mathrm{w}$ wydarzeniach rewolucyjnych, a zabezpieczone zostają nowym porządkiem symbolicznym.

\section{PERMANENTNE MARZENIE EMANCYPACYJNE - ZAKOŃCZENIE}

Bacznie obserwowana historia dziejów ludzkich zawiera mnóstwo przejawów emancypacyjnych marzeń i dążeń tych, którzy znaleźli się w proletariackim położeniu. Rewolucja każdorazowo stanowi spełnienie się - w mniejszym lub większym stopniu - tych emancypacyjnych marzeń. Lenin z roku 1917 stał się dla Žižka symbolem emancypacyjnej postawy i dlatego uważał on, że „Lenin był w Warszawie w latach siedemdziesiątych i osiemdziesiątych, a jego duch inspirował protesty robotników, na bazie których wyrosła "Solidarność «" (Žižek, 2017, s. LXXX). Nie tęskni więc Žižek - co wmawiają mu niektórzy - za Leninowską wersją komunizmu w jego wymiarze politycznym czy gospodarczym, ale tęskni za „leninowską postawą”. W Rewolucji u bram mówi expressis verbis, że „powtórzenie Lenina nie oznacza powrotu do Lenina” - „powtórzenie Lenina oznacza, że musimy odróżnić między tym, co Lenin faktycznie zrobił i otwartym przez niego polem możliwości” (Žižek, 2007, ss. 625-626). Jego zdaniem dziś potrzebujemy przywódców, którzy na nowo podniosą emancypacyjne postulaty i domagać się będą prawdziwej rewolucji. Współczesny homo sacer już wypatruje swojego obrońcy, który zarysuje nowy „komunistyczny horyzont”. Tak samo bowiem, jak robotnicy (proletariat sensu stricto) stanowili bazę polityczną bolszewików i rewolucji październikowej, chłopi - maoistów i rewolucji chińskiej, tak też dziś wykształcić się powinna świadomość klasowa nowych ciemiężonych (Žižek, 2019, ss. 48-49). Kiedy więc Žižek mówi o powtórzeniu rewolucji październikowej, wówczas na myśli ma raczej formę zakwestionowania dzisiejszego porządku symbolicznego aniżeli treściową zawartość, jaką „nowemu porządkowi” nadała Wszechrosyjska Komunistyczna Partia (bolszewików) po 1917 r. Ma na myśli raczej historyczny impas, w jakim znaleźliśmy się współcześnie, i ciężar decyzji, przed którą staną przyszli rewolucjoniści, aniżeli powrót do popaździernikowego porządku (Žižek, 1992, s. 79). Jego zdaniem nadszedł 
już czas, aby zakwestionować współczesny - dominujący w zglobalizowanym świecie - porządek symboliczny i dopuścić do głosu nowych wykluczonych.

W Żądaniu niemożliwego Žižek stwierdza dobitnie, że „miraż kapitalizmu z demokracją dobiegł końca” (Žižek, 2014b, s. 44) i że niechybnie „zmierza do rozwodu" (Žižek, 2014b, s. 86). Późny kapitalizm stał się - jego zdaniem - formą rządów globalnej oligarchii, która niewiele ma wspólnego ze Smithowskim ideałem niewidzialnej ręki rynku. Demokracja parlamentarna tymczasem - jak twierdzi - stała się fasadą. Państwa tzw. liberalnej demokracji borykają się z problemem „nieobecności prawdziwych wyborów”, gdyż ich przebieg oraz wyniki „tak naprawdę już się nie liczą, zostały strywializowane” (Žižek, 2007, s. 308). Z kolei triumf „postpolityki w najczystszej postaci” oraz wzrost „popularności menedżerskiego podejścia do rządzenia” (Žižek, 2007, s. 609) doprowadziły do eliminacji polityczności ze sfery nomen omen polityki. Jeśli więc przyjąć, że rewolucja jest jedyną i najlepszą szansą na emancypację nowych wykluczonych, to najwyższy czas, aby otworzyć pole dla nowych radykałów w polityce. Przyszły rewolucyjny przywódca nie ma powtarzać działań Lenina, ale powinien wykorzystać jego stracone szanse i poszerzyć obszar emancypacji o tereny, których Leninowi zdobyć się nie udało, bądź te, o których zdobyciu nawet nie mógł marzyć (Žižek, 2007, s. 626). Jak więc widać, Žižka koncepcja rewolucji jako emancypacji ma swój wymiar uniwersalny: rewolucja ma wyrastać z krytyki panującego porządku symbolicznego, rewolucja ma być nośnikiem radykalnych celów i środków, wreszcie rewolucja ma stanowić ekspresję nieskrępowanej wolności tych, którzy się buntują.

\section{BIBLIOGRAFIA:}

Agamben, G. (2008). Homo sacer. Suwerenna władza i nagie życie. Warszawa: Prószyński i S-ka.

Bjerre, H. J., Laustsen, C. B. (2010). The Subject of Politics: Slavoj Žižek's Political Philosophy. Penrith: Humanities-Ebooks.

Boucher, G. (2020). Revolutionary Hope in Dark Times: Žižek on Faith in the Future. Religions, 11(5), 243-257.

Breckman, W. (2016). Adventures of the Symbolic: Post-Marxism and Radical Democracy. New York: Columbia University Press.

Burman, A. (2018). A Lacanian Hegelianism: Slavoj Žižek (Mis)Reading of Hegel, W: A. Burman, A. Baronek (red.). Hegelian Marxism: The Uses of Hegel's Philosophy in Marxist Theory from Georg Lukács to Slavoj Žižek (ss. 185-198). Huddinge: Södertörns högskola.

Burzyk, M. (2013). Psychoanaliza a polityka: stawka podmiotu. Diametros, 35, 1-20. 
Dybel, P. (1996). Freuda sen o kulturze. Warszawa: Instytut Kultury.

Dybel, P. (2014). Rozterki podmiotu politycznego radykalnej lewicy, czyli Žižek pod bramą rewolucji. W: K. Kłosiński, D. Matuszak (red.). Polityczność psychoanalizy. Freud - Lacan - Žižek (ss. 41-75). Katowice: Wydawnictwo Uniwersytetu Śląskiego.

Finlay, C. J. (2006). Violence and Revolutionary Subjectivity: Marx to Žižek. Dublin: Geary Institute.

Flisfeder, M. (2008). Reading Emancipation Backwards: Laclau, Žižek and the Critique of Ideology in Emancipatory Politics. International Journal of Žižek Studies, 2(1), $1-22$.

Freud, Z. (1994). Poza zasada przyjemności. Warszawa: Wydawnictwo Naukowe PWN. Hobsbawm, E. (1996). Out of the Great Dark Whale. London Review of Books, 18(21), 3-5.

Kaczmarek, A. (2015). Pomiędzy erosem a tanatosem: Susan Sontag/Annie Leibovitz. Tematy z Szewskiej, 2(16), 39-51.

John, O. P., Pervin, L. A. (2011). Osobowość. Teoria i badania. Kraków: Wydawnictwo Uniwersytetu Jagiellońskiego.

Khader, J., Rothenberg, M. A. (2013). Žižek Now: Current Perspectives in Žižek Studies. Cambridge: Polity.

Jameson, F. (2010). Lacan i dialektyka: fragment. ER(R)GO. Teoria - Literatura - Kultura, 1-2 (20/21), 255-290.

Laclau, E. (1990). Reflections of the Revolution of Our Time. London-New York: Verso.

Laclau, E. (2006). Why Constructing a People Is the Main Task of Radical Politics. Critical Inquiry, 32(4), 646-680.

Laclau, E., Mouffe, Ch. (2007). Hegemonia i socjalistyczna strategia. Przyczynek do projektu radykalnej polityki demokratycznej. Wrocław: Wydawnictwo Naukowe Dolnośląskiej Szkoły Wyższej Edukacji TWP.

Mazur, Ł. N. (2017). Ot istorii oktiabria k istorii russkoj riewolucyi: srawnitielnyj analiz mietodołogiczeskich podchodow k ocenkie sobytij 1917 g. Izwiestija Uralskogo fiedieralnogo uniwiersitieta. Gumanitarnyje nauki (Sierija 2), 19(3), 3-27.

McMillan, C. (2021). Žižek and Communist Strategy: On the Disavowed Foundations of Global Capitalism. Edinburgh: Edinburgh University Press.

Miklitsch, R. (1998). Psycho-Marxism: Marxism and Psychoanalysis Late in the Twentieth Century. Durham: Duke University Press.

Przyłęcki, P. (2013). Założenia teorii dyskursu Ernesta Laclaua i Chantal Mouffe. Przegląd Socjologiczny, 62(4), 9-24.

Reed, J. (1956). Dziesięć dni, które wstrząsnęły światem. Warszawa: Książka i Wiedza.

Sigurdson, O. (2012). Theology and Marxism in Eagleton and Žižek: A Conspiracy of Hope. New York: Palgrave Macmillan.

Vighi, F. (2010). On Žižek’s Dialectics: Surplus, Substraction, Sublimation. London-New York: Continuum International Publishing Group.

Wójcik, B. (2014). Žižka powrót do Hegla. W: K. Kłosiński, D. Matuszak (red.). Polityczność psychoanalizy. Freud - Lacan - Žižek (ss. 219-235). Katowice: Wydawnictwo Uniwersytetu Śląskiego. 
Wójcik, B. (2016). Lekcje rewolucjonisty: Lenin czyta Hegla. Praktyka Teoretyczna, 2(20), 18-41. DOI: 10.14746/prt.2016.2.1.

Žižek, S. (1992). Enjoy Your Symptom! Jacques Lacan in Hollywood and out. New York - London: Routledge.

Žižek, S. (2001). Przekleństwo fantazji. Wrocław: Wydawnictwo Uniwersytetu Wrocławskiego.

Žižek S. (2006). Kukła i karzeł. Perwersyjny rdzeń chrześcijaństwa. Bydgoszcz - Warszawa - Wrocław: Oficyna Wydawnicza Branta.

Žižek S. (2007). Rewolucja u bram: Pisma Lenina z roku 1917. Kraków: Wydawnictwo Krytyki Politycznej.

Žižek, S. (2008a). Lacan. Przewodnik Krytyki Politycznej. Warszawa: Wydawnictwo Krytyki Politycznej.

Žižek, S. (2008b). W obronie przegranych spraw. Warszawa: Wydawnictwo Krytyki Politycznej.

Žižek, S. (2008c). For They Know Not What They Do. Enjoyment as a Political Factor. London-New York: Verso.

Žižek, S. (2011). Living in the End of Times. London-New York: Verso.

Žižek, S. (2014a). Rok niebezpiecznych marzeń. Warszawa: Wydawnictwo Krytyki Politycznej.

Žižek, S. (2014b). Żądanie niemożliwego. Warszawa: Wydawnictwo Aletheia.

Žižek, S. (2016). Biegnij, Antygono, biegnij! Krytyka Polityczna, 46, 235-248.

Žižek, S. (2017). Lenin 2017. Remembering, Repeating and Working Through. LondonNew York: Verso.

Žižek, S. (2018). Patrząc z ukosa. Wprowadzenie do Jacques'a Lacana przez kulture popularna. Warszawa: Wydawnictwo Aletheia.

Žižek, S. (2019). The Relevance of the Communist Manifesto, Cambridge-Medford: Polity Press.

Žižek, S. (2020). Pandemia! COVID-19 trzęsie światem. Warszawa: Wydawnictwo Relacja. 